\title{
Significance of I313V mutation of NLPR3 gene in two pediatric patients
}

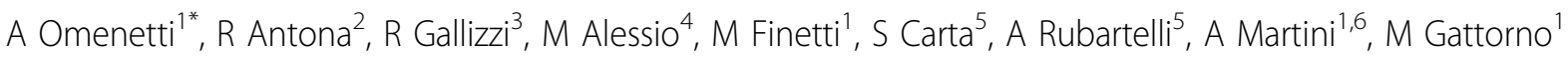 \\ From 18th Pediatric Rheumatology European Society (PReS) Congress \\ Bruges, Belgium. 14-18 September 2011
}

\section{Background}

The I313V mutation of the NLRP3 gene has been only anecdotally reported and described in association with the so-called Magic Syndrome (Infevers database). However, nor the clinical or pathophysiological significance of such mutation has been so far reported.

\section{Aim}

To describe the clinical picture of patients carrying the I313V mutation and its consequences in IL- $1 \beta$ secretion.

\section{Methods}

Two families carrying NLRP3 I313V mutation were evaluated. Monocytes were obtained from patients and their parents. Cells isolated from healthy donors (HD) $(\mathrm{N}=14)$ were used as negative control group. Pattern of secretion of IL- $1 \beta$, IL-1Ra, IL- 6 and IL- 8 were then assessed by ELISA in the presence or absence exogenous LPS.

\section{Results}

Both case \#1 (M.T) and \#2 (V.C) displayed a mild clinical phenotype (episodes of urticarial rash and arthralgia associated with elevation of acute phase reactants), compatible with FCAS and Muckle-Wells syndrome, respectively. Both patients displayed good response to NSAID and/or steroid on demand. Compared to HD controls, patients displayed enhanced and delayed IL1 $\beta$ secretion. This was accompanied by higher levels of IL1Ra and IL-6 without any significant differences in IL-8. Interestingly, parents carrying the mutation also displayed higher levels of secreted IL-1 $\beta$ compared to HD control group.

* Correspondence: alessia.omenetti@gmail.com

'Department of Pediatrics, G Gaslini Institute, Genoa

Full list of author information is available at the end of the article

\section{Conclusion}

The I313V mutation is associated with a mild CAPS phenotype and with an increased IL- $1 \beta$ secretion.

\section{Author details \\ ${ }^{1}$ Department of Pediatrics, G Gaslini Institute, Genoa. ${ }^{2}$ Department of Pediatrics, University of Palermo. ${ }^{3}$ Department of Pediatrics, University of Messina. ${ }^{4}$ Department of Pediatrics, University of Naples. ${ }^{5}$ Cell Biology Unit, National Cancer Research Institute, Genoa. ${ }^{6}$ Department of Pediatrics, University of Genoa.}

Published: 14 September 2011

doi:10.1186/1546-0096-9-S1-P305

Cite this article as: Omenetti et al.: Significance of I313V mutation of NLPR3 gene in two pediatric patients. Pediatric Rheumatology 20119 (Suppl 1):P305.
Submit your next manuscript to BioMed Central and take full advantage of:

- Convenient online submission

- Thorough peer review

- No space constraints or color figure charges

- Immediate publication on acceptance

- Inclusion in PubMed, CAS, Scopus and Google Scholar

- Research which is freely available for redistribution
C Biomed Central 